\title{
Pašarinio papildo kaolino E 559 poveikis telyčių augimui, vystymuisi ir reprodukcijai
}

\author{
Arvydas Kardišauskas ${ }^{1}$, \\ Rima Kregždyté2 \\ ${ }^{1}$ Marijampolés kolegija, \\ P. Armino g. 92, \\ LT-68125 Marijampole \\ El.paštas kardisauskas@gmail.com \\ ${ }^{2}$ Lietuvos sveikatos mokslu universitetas, \\ A. Mickevičiaus g. 9, LT-44307 Kaunas \\ El.paštas rima.kregzdyte@lsmuni.lt
}

\begin{abstract}
Telyčiu augintojų ūkinės veiklos ekonominis efektyvumas priklauso ne tik nuo optimalių jų augimo, vystymosi rodiklių, bet ir reprodukciniu gyvulio savybių.

Darbo tikslas - ištirti kaolino E 559 poveikị telyčiu augimui, vystymuisi ir reprodukcijai.

Tikslui pasiekti buvo sudarytos dvi Lietuvos juodmargiu galviju veislès veršeliu grupès (kontrolinè ir bandomoji) po penkiolika vienetų. Bandymas vykdytas dviem etapais - nuo 2012 m. kovo iki 2014 m. vasario mènesio. Pirmasis etapas - nuo veršelio 5 gimimo dienos iki 12 menesių amžiaus. Šiame etape buvo tiriamas telyčių augimas ir vystymasis, antrajame etape - apsivaisinimas. Telyčios buvo auginamos viename tvarte ir vienodomis sąlygomis, tik bandomajai grupei papildomai buvo duodama kaolino (100 kg koncentruotų pašaru $+2,5 \mathrm{~kg}$ kaolino). Bandomosios grupés vidutinis veršelių priesvoris buvo 3,58 \% didesnis nei kontrolinès $(\mathrm{p}>0,05)$, bendras priaugimas - didesnis 3,96\% $(\mathrm{p}>0,05)$, didesnis hemoglobino $27 \mathrm{~g} / \mathrm{l}(\mathrm{p}>0,05)$ ir gliukozès $0,41 \mathrm{mmol} / \mathrm{l}(\mathrm{p}<0,05)$ kiekis kraujyje. Bandomosios grupès telyčios $2,4 \%$ geriau apsivaisino $(p>0,05)$ ir vienu mènesiu anksčiau apsiveršiavo nei kontrolinès grupès telyčios $(\mathrm{p}>0,05)$.
\end{abstract}

Raktažodžiai: kaolinas E 559, telyčios, veršelių augimas, reprodukcija

\section{IVADAS}

Mažinant pieno gamybos savikainą yra svarbu ieškoti būdų, kaip ekonomiškiau užauginti telyčias. Viena iš priemonių - auginat telyčias naudoti aliumosilikatus. Aliumosilikatai - natūralios mineralinès žaliavos (zeolitai, bentonitai, apatitai, diatomitai, sepiolite, kaolinas ir kt.). Dèl jų fizinių ir cheminių charakteristikų, gamtinès arba organinès formos gali gerai absorbuoti toksinus, toksinius metalus $(\mathrm{Pb}, \mathrm{Cu}, \mathrm{Cd}, \mathrm{Mn}, \mathrm{Zn}, \mathrm{Cr}, \mathrm{Ni}$ ), radionuklidus (Cs, U, Ra, I), amoniaką, karbo dioksidą, metaną ir kitus organinius teršalus (Adamović et al., 2011).

Kaolinas yra minkštas plastiškas molis, daugiausia susidedantis iš mineralo kaolinito, kuris yra hidratuotas aliuminio silikatas $\mathrm{Al}_{2} \mathrm{O}_{32} \mathrm{SiO}_{22} \mathrm{H}_{2} \mathrm{O}$ (Murray, 2002). Toksinai yra viena iš pagrindinių priežasčių, lemiančių viduriavimą, mažą priesvorị, blogą pašarų įsisavinimą, imuniteto susilpnèjimą (Huwig et al., 2001). Mikotoksinai turi negatyvu poveiki ne tik pašarų pasisavinimui, bet ir produktyvumui. Jų buvimas gyvuliniuose produktuo- se - mėsoje, piene, kiaušiniuose - turi neigiamą poveiki žmonių sveikatai (Ani et al., 2014). Nustatytas teigiamas absorbavimo efektas ne tik kaolino, bet ir molžemio mineralų (montmorillonitų, zeolitų), kurie detoksikuoja organizmą ir gali būti naudojami diarejos prevencijai (Trckova et al., 2004). Buvo tyrinejjamas kaolino ir kitų silikatinių moliu poveikis paukščiu (Safaei Katouli et al., 2010, 2011; Owen et al., 2012; Ani et al., 2014), kiaulių (Trckova et al., 2004; Ambrasūnas et al., 2013), veršelių (Lee et al., 2010), triušių (Wafar et al., 2014) ir žiurkių (Grosicki, Rachubik, 2005; Demirel et al., 2011; Liang et al., 2013) priesvoriui. Molžemio poveikio efektyvumas priklauso nuo įdedamo kiekio ì pašarus (Safaei Katouli et al., 2011).

\section{TYRIMO METODAI IR SĄLYGOS}

Tyrimui buvo atrinkti 30 Lietuvos juodmargiu veislès pirmos-ketvirtos laktacijos karvių veršeliai. Pagal sèklinimui naudotų bulių linijas, siekiant išvengti tèvo ịtakos tolimesniam veršelių augimui, 
suformuota bandomoji ir kontrolinè grupès po 15 veršelių. Formuojant grupes atsižvelgta $\mathfrak{i}$ karvių laktacijų skaičiu bei produktyvumą. Nuo pirmosios dienos veršeliai buvo laikomi vienutèse, nuo $31 \mathrm{~d}$. laikyti grupèse po 8 veršelius.

Pašarinis priedas kaolinas E 559 pradètas naudoti šèrimui nuo 5 dienos amžiaus. Veršeliams šerti naudojamas starterinis pašaras, pienas ir kaolinas E 559. Nuo 5 iki 30 dienos amžiaus i $1 \mathrm{~kg}$ starterinio pašaro buvo dedama 25 g kaolino E 559. Nuo 31 dienos amžiaus veršeliams duotas koncentruotas pašaras - $\mathfrak{i} 1 \mathrm{~kg}$ pašaro buvo dedama $25 \mathrm{~g}$ kaolino, taip pat pieno, šieno, šienainio, kukurūzų siloso. Abiejų grupių telyčiu racionai buvo subalansuoti pagal apykaitinę energiją, žaliuosius baltymus, žaliąją ląstelieną, Ca ir P santykį. 7-9 mènesių amžiaus telyčioms $1 \mathrm{~kg} \mathrm{SM}$ buvo 10,5 AE MJ, 14,8 \% žaliųjų baltymų, 22,4 \% žaliosios ląstelienos, Ca ir P santykis - 1,65:1, 10-12 mènesiu amžiaus - $1 \mathrm{~kg}$ SM buvo 10,3 AE MJ, 13,6 \% žaliujų baltymų, 24,4 \% žaliosios ląstelienos, $\mathrm{Ca}$ ir $\mathrm{P}$ santykis - 1,68:1. Bandymo laikotarpiu buvo stebima veršelių sveikatos būklè, pašarų suėdamumas, rujos intensyvumas. Kraujo méginiai buvo imami i sterilius vienkartinius vakuuminius mégintuvelius („Venoject“, Terumo Europe N. V., Belgium), padengtus silikono sluoksniu. Kraujas imtas iš uodegos, naudotos sterilios vienkartinès adatos („Venoject" needle, Terumo Europe N. V., Belgium), jų diametras $-0,9 \times 40 \mathrm{~mm}$. Paimti kraujo mèginiai per 1 val. buvo pristatomi i laboratoriją, ten kraujo morfologiniai tyrimai buvo atliekami automatiniu hematologiniu analizatoriumi BC-2800, o bioche- miniai kraujo tyrimai - IDEXX VetTest analizatoriumi. Tyrimo metu bandomosios ir kontrolinès grupių veršeliai sverti kiekvieną mènesị.

Duomenys analizuoti SPSS 20 statistinès analizès paketu. Skaičiuota aprašomoji statistika: vidurkis, vidutinis kvadratinis nuokrypis, įvairavimo koeficientas, vidurkio paklaida. Lyginant kiekybinius duomenis (paros priesvoris, bendras priesvoris, apsiveršiavimo amžius, kraujo morfologiniai rodikliai) tarp bandomosios ir kontrolinès grupès taikytas neparametrinis Mann-Whitney kriterijus. Skirtumai laikyti statistiškai reikšmingais, kai $\mathrm{p}<0,05$.

\section{REZULTATAI IR JŲ APTARIMAS}

Bandymai parodè, kad kaolino E 559 priedas lèmè spartesni gyvulių augimą. Bendras abiejų grupių telyčiu masès priaugimas pateiktas paveiksle.

Kaip matome paveiksle pateiktose diagramose, kontrolinès ir bandomosios grupès telyčių svorių skirtumas išryškèjo pasibaigus pieno girdymo laikotarpiui. Pradèjus veršelius šerti žoliniais pašarais, bandomosios grupès telyčių svoris padidejjo 6,96 \% daugiau negu kontrolinès ( $\mathrm{p}>0,05)$, nes veršeliu racionas buvo subalansuotas, o pieno girdymo laikotarpiu koalinas E 559 poveikio svoriui neturejjo. 1 lentelëje pateiktas kontrolinès ir bandomosios grupių telyčių paros priesvorio rodiklių palyginimas.

Iš 1 lentelëje pateiktų duomenų matome, kad bandomajį laikotarpị telyčių, šertų su kaolinu, paros priesvoris buvo 3,96 \% didesnis ( $p>0,05)$ nei kontrolinès, taip pat mažesnis ịvairavimo koeficientas, parodantis

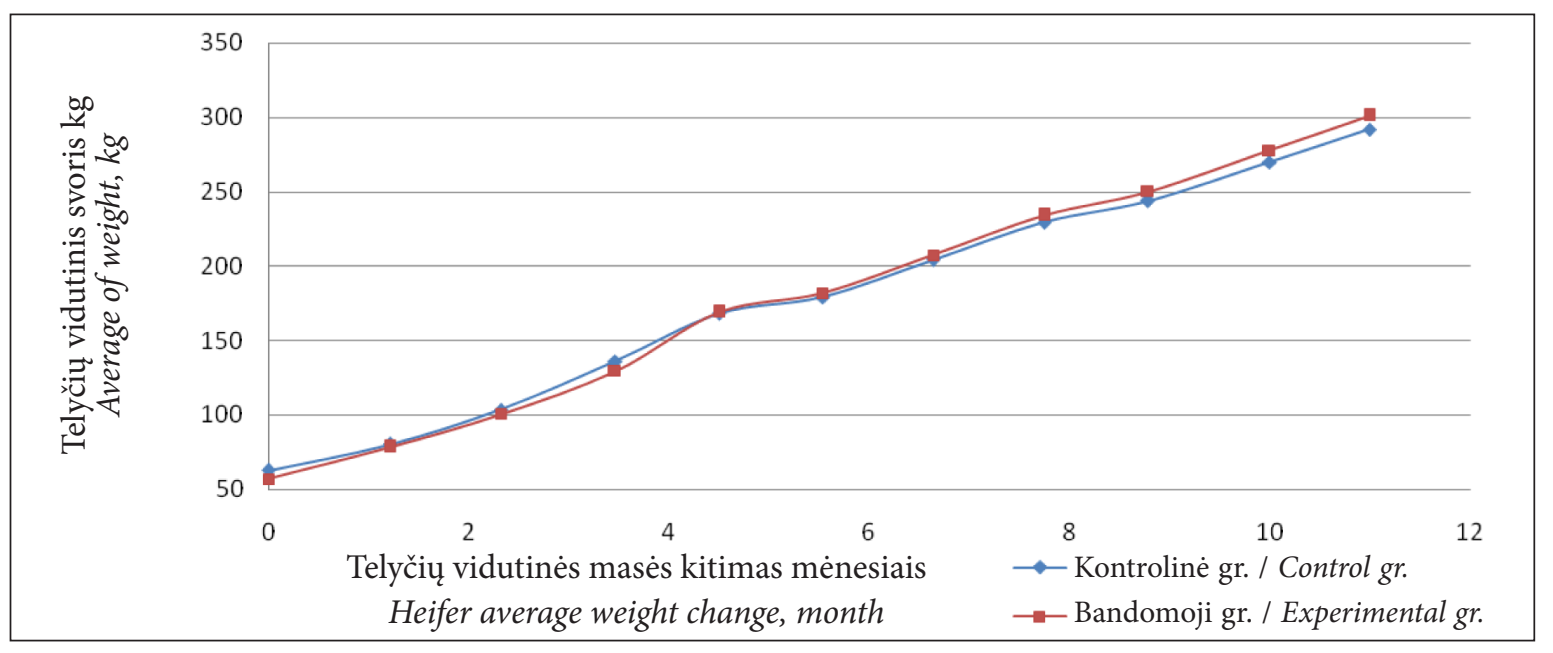

Pav. Telyčių vidutinès masès kitimas mènesiais

Figure. Heifer average weight change, month 
1 lentelè. Vidutinis telyčių paros priesvoris $\mathrm{kg}$

Table 1. Heifer average daily gain, $\mathrm{kg}$

\begin{tabular}{|c|c|c|c|}
\hline Rodikliai / Parameter & 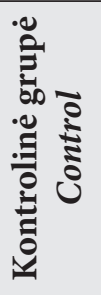 & 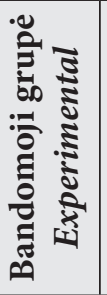 & e. \\
\hline $\begin{array}{l}\text { Narių skaičius } \mathrm{n} \\
\text { Number of members }\end{array}$ & 15 & 15 & \multirow{4}{*}{0,272} \\
\hline Vidurkis $\overline{\mathrm{x}} /$ Mean & 0,727 & 0,757 & \\
\hline $\begin{array}{l}\text { Vidutinis kvadratinis nuokrypis } \\
\text { Standard deviation }\end{array}$ & 11,42 & 8,59 & \\
\hline $\begin{array}{l}\text { Ivairavimo koeficientas \% } \\
\text { Coefficient of variation }\end{array}$ & 0,021 & 0,017 & \\
\hline
\end{tabular}

telyčių tolygesni augimą. Kitų tyrëjų duomenimis, paros priesvorio rezultatai su koalinu E 559 buvo: veršelių - 14,2 \%, buliukų penèjimo metu - 9,8 \%, paršelių - 9,6 \% (Utizhev, 2011), paršelių - 10,06 \% (Ambrasūnas, 2013), broilerių - 12,9 \% (Owen et al., 2014), penimų galvijų 11,3\% (Lee et al., 2011).

Iš 2 lenteleje pateiktų duomenų matome, kad bendras bandomosios telyčių grupès priesvoris buvo 3,58\% didesnis nei kontrolinès ( $\mathrm{p}>0,05)$. Ivairavimo koeficientas kontrolinès grupès yra didesnis negu bandomosios, tai parodo tolygesni bandomosios grupès telyčių priaugimą, kurị galèjo lemti pašarinis papildas kaolinas E 559.
Bandymo metu telyčios, sulaukusios 15 mėnesių amžiaus ir pasiekusios ne mažesni kaip $380 \mathrm{~kg}$ svorị, buvo pradètos sèklinti. Bandomosios grupès telyčios pirmą kartą rujos pažymiai pasireiške 15,2 mènesio, kontrolinèms - 16,5 mènesio. Iš 3 lentelèje pateiktų duomenų matome, kad telyčių išsaugojimas iki apsiveršiavimo bandomosios grupès buvo $7,1 \%$ didesnis nei kontrolinès; bandomosios grupes telyčios apsiveršiavo 1 ménesiu anksčiau, palyginti su kontroline grupe $(\mathrm{p}>0,05)$.

3 lentelè. Telyčių vidutinis amžius pirmojo veršiavimosi metu mèn.

Table 3. Heifer average age at the first calving, months

\begin{tabular}{|c|c|c|}
\hline Rodikliai / Parameter & 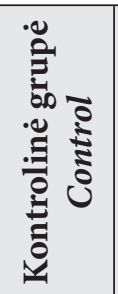 & 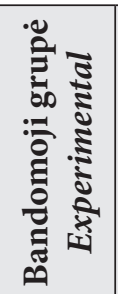 \\
\hline $\begin{array}{l}\text { Narių skaičius } \mathrm{n} \\
\text { Number of members }\end{array}$ & 13 & 14 \\
\hline Vidurkis $\overline{\mathrm{x}} /$ Mean & 26,69 & 25,56 \\
\hline $\begin{array}{l}\text { Vidutinis kvadratinis nuokrypis } \\
\text { Standard deviation }\end{array}$ & 2,25 & 1,50 \\
\hline $\begin{array}{l}\text { Ivairavimo koeficientas \% } \\
\text { Coefficient of variation }\end{array}$ & 8,43 & 5,87 \\
\hline $\begin{array}{l}\text { Aritmetinio vidurkio paklaida } \\
\text { Standard error of mean }\end{array}$ & 0,62 & 0,40 \\
\hline
\end{tabular}

2 lentelè. Telyčiu svoris bandymo pradžioje ir pabaigoje kg

Table 2. Heifer weight at the beginning and at the end, $\mathbf{k g}$

\begin{tabular}{|c|c|c|c|c|c|c|c|c|c|}
\hline \multirow[t]{2}{*}{$\begin{array}{l}\text { Bandymo mėnesiai } \\
\text { Test months }\end{array}$} & \multicolumn{3}{|c|}{$\begin{array}{c}\text { Kontrolinė grupè } \\
\text { Control }\end{array}$} & \multicolumn{3}{|c|}{$\begin{array}{c}\text { Bandomoji grupè } \\
\text { Experimental }\end{array}$} & \multicolumn{3}{|c|}{$\begin{array}{l}\text { Bandomosios grupės } \\
\text { telyčiu masė, palyginti } \\
\text { su kontroline grupe } \\
\text { Heifer weight of the } \\
\text { experimental group } \\
\text { compared to } \\
\text { the control group }\end{array}$} \\
\hline & $\mathbf{X} \pm S x$ & SN & CV & $X \pm S x$ & SN & $\mathrm{CV}$ & kg & $\%$ & p \\
\hline $\begin{array}{l}\text { Bandymo pradžia } \\
\text { At the beginning }\end{array}$ & $42,67 \pm 1,52$ & 5,9 & 13,83 & $42,73 \pm 1,08$ & 4,2 & 9,83 & 0,06 & 0,14 & 0,972 \\
\hline $\begin{array}{l}\text { Bandymo pabaiga } \\
\text { At the end }\end{array}$ & $292,67 \pm 8,62$ & 33,37 & 11,4 & $301,67 \pm 5,89$ & 22,81 & 7,56 & 9 & 3,08 & 0,396 \\
\hline $\begin{array}{l}\text { Padidèjo mase per } \\
\text { bandymu laikotarpi } \\
\text { Increase in weight } \\
\text { during the test period }\end{array}$ & $250,00 \pm 8,47$ & 32,81 & 13,12 & $258,94 \pm 5,81$ & 22,51 & 8,69 & 8,94 & 3,58 & 0,392 \\
\hline
\end{tabular}

$\mathrm{X}$ - vidurkis, $\mathrm{S} \mathrm{X}$ - vidurkio paklaida, $\mathrm{SN}$ - standartinis nuokrypis, $\mathrm{CV}$ - ịvairavimo koeficientas. 
Iš 4 lentelëje pateiktų duomenų matome, kad papildas kaolinas E 559 turèjo nežymią itaką telyčių vaisingumui $(p>0,05)$. Kontrolinei grupei sunaudota 1,71 spermos dozių, o bandomajai - 1,67, t. y. $2,4 \%$ mažiau.
Iš 5 lentelëje pateiktų duomenų matome, kad ir kontrolinès, ir bandomosios grupès telyčių kraujo morfologiniai rodikliai atitiko fiziologines normas. Bandomosios grupès leukocitai padidejo 6,10 $\left(\times 10^{9} / 1\right)$, o kontrolinès - 11,53 $\left(\times 10^{9} / \mathrm{l}\right)(\mathrm{p}>0,05)$.

4 lentelè. Telyčiu sèklinimo rezultatai

Table 4. Heifer insemination results

\begin{tabular}{|c|c|c|c|}
\hline Rodikliai / Parameter & $\begin{array}{l}\text { Kontrolinè grupè } \\
\text { Control }\end{array}$ & $\begin{array}{l}\text { Bandomoji grupè } \\
\text { Experimental }\end{array}$ & $\mathbf{p}$ \\
\hline Narių skaičius $\mathrm{n} /$ Number of members & 13 & 14 & \multirow{5}{*}{0,903} \\
\hline Sëklinimo kartų vidurkis $\overline{\mathrm{x}} /$ Mean & 1,71 & 1,67 & \\
\hline Vidutinis kvadratinis nuokrypis / Standard deviation & 1,14 & 0,90 & \\
\hline Ivairavimo koeficientas \% / Coefficient of variation & 66,67 & 53,89 & \\
\hline Aritmetinio vidurkio paklaida / Standard error of mean & 0,30 & 0,23 & \\
\hline
\end{tabular}

5 lentelè. Telyčių kraujo morfologiniai rodikliai

Table 5. Heifer blood morphological parameters

\begin{tabular}{|c|c|c|c|c|c|c|c|c|}
\hline \multirow{2}{*}{$\begin{array}{l}\text { Rodikliai } \\
\text { Parameter }\end{array}$} & \multirow{2}{*}{$\begin{array}{c}\text { Norma } \\
\text { Norm }\end{array}$} & \multicolumn{2}{|c|}{$\begin{array}{l}\text { Bandomoji grupė } \\
\text { Experimental }\end{array}$} & \multirow{2}{*}{$\begin{array}{l}\text { Pokytis } \\
\text { Change }\end{array}$} & \multicolumn{2}{|c|}{$\begin{array}{c}\text { Kontrolinè grupė } \\
\text { Control }\end{array}$} & \multirow{2}{*}{$\begin{array}{l}\text { Pokytis } \\
\text { Change }\end{array}$} & \multirow[b]{2}{*}{$\mathbf{p}$} \\
\hline & & $\begin{array}{c}\text { Pradžioje } \\
\text { At the } \\
\text { beginning }\end{array}$ & $\begin{array}{l}\text { Pabaigoje } \\
\text { At the end }\end{array}$ & & $\begin{array}{c}\text { Pradžioje } \\
\text { At the } \\
\text { beginning }\end{array}$ & $\begin{array}{l}\text { Pabaigoje } \\
\text { At the end }\end{array}$ & & \\
\hline $\begin{array}{c}\mathrm{WBC}\left(\times 10^{9} / 1\right) \\
\text { Leukocitu skaičius } \\
\text { Leucocytes }\end{array}$ & $5,0-16,0$ & 11,13 & 17,23 & 6,10 & 14,47 & 26,00 & 11,53 & 0,513 \\
\hline $\begin{array}{c}\mathrm{RBC}\left(\times 10^{12} / \mathrm{l}\right) \\
\text { Eritrocitų skaičius } \\
\text { Erythrocytes }\end{array}$ & $5,0-10,1$ & 7,36 & 8,47 & 1,11 & 8,29 & 7,12 & $-1,17$ & 0,127 \\
\hline $\begin{array}{c}\text { HGB g/l } \\
\text { Hemoglobinas } \\
\text { Haemoglobin }\end{array}$ & $90-139$ & 104,67 & 131,67 & 27,00 & 107,0 & 93,00 & $-14,00$ & 0,127 \\
\hline
\end{tabular}

6 lentelè. Telyčiu kraujo biocheminiai rodikliai

Table 6. Heifer blood biochemical parameters

\begin{tabular}{|c|c|c|c|c|c|c|c|c|}
\hline \multirow{2}{*}{$\begin{array}{l}\text { Rodikliai } \\
\text { Parameter }\end{array}$} & \multirow{2}{*}{$\begin{array}{l}\text { Norma } \\
\text { Norm }\end{array}$} & \multicolumn{2}{|c|}{$\begin{array}{l}\text { Bandomoji grupè } \\
\text { Experimental }\end{array}$} & \multirow{2}{*}{$\begin{array}{l}\text { Pokytis } \\
\text { Change }\end{array}$} & \multicolumn{2}{|c|}{$\begin{array}{l}\text { Kontrolinè grupè } \\
\text { Control }\end{array}$} & \multirow{2}{*}{$\begin{array}{l}\text { Pokytis } \\
\text { Change }\end{array}$} & \multirow[b]{2}{*}{$\mathbf{p}$} \\
\hline & & $\begin{array}{l}\text { Pradžioje } \\
\text { At the } \\
\text { beginning }\end{array}$ & $\begin{array}{l}\text { Pabaigoje } \\
\text { At the end }\end{array}$ & & $\begin{array}{l}\text { Pradžioje } \\
\text { At the } \\
\text { beginning }\end{array}$ & $\begin{array}{c}\text { Pabaigoje } \\
\text { At the } \\
\text { end }\end{array}$ & & \\
\hline $\begin{array}{c}\text { GLU mmol/l } \\
\text { Gliukozè / Glucose }\end{array}$ & $3,11-4,77$ & 4,60 & 5,01 & 0,41 & 4,31 & 3,98 & $-0,33$ & 0,127 \\
\hline $\begin{array}{l}\text { BUN mmol/l } \\
\text { Šlapalas / Urea }\end{array}$ & $0,55-1,39$ & 0,94 & 1,11 & 0,17 & 1,05 & 0,90 & $-0,15$ & 0,043 \\
\hline $\begin{array}{c}\mathrm{TP} g / \mathrm{l} \\
\text { Bendras baltymas } \\
\text { Total protein }\end{array}$ & $\begin{array}{c}0,062- \\
0,080\end{array}$ & 0,063 & 0,067 & 0,004 & 0,067 & 0,068 & 0,001 & 0,513 \\
\hline
\end{tabular}


Eritrocitai bandomosios grupès padidejo 1,11 $(\times 1012 / 1)$, o kontrolinès - sumažëjo $1,17(\times 1012 / 1)$ ( $p>0,05)$, hemoglobinas bandomosios grupés padidèjo $27 \mathrm{~g} / \mathrm{l}$, kontrolinès - sumažèjo $14 \mathrm{~g} / \mathrm{L}(\mathrm{p}>0,05)$.

Iš 6 lenteleje pateiktų duomenų matome, kad bandomosios grupès veršelių kraujyje gliukozès bandymo pradžioje, palyginti su bandymo pabaiga, padidejo $0,41 \mathrm{mmol} / \mathrm{l}$, o kontrolinès - sumažèjo $0,33 \mathrm{mmol} / \mathrm{l}(\mathrm{p}<0,05)$, šlapalas bandomosios grupès padidèjo $0,17 \mathrm{mmol} / \mathrm{l}$, o kontrolinès - sumažèjo $0,15 \mathrm{mmol} / \mathrm{l}(\mathrm{p}<0,05)$, bendrasis baltymas bandomosios grupès padidèjo 0,004 g/l, kontrolinès - 0,001 mg/dL ( $\mathrm{p}>0,05)$. Didesnis hemoglobino ir gliukozès kiekis kraujyje rodo intensyvesnę veršelių medžiagų apykaitą.

\section{IŠVADOS}

1. Bandymų rezultatai parodè, kad papildas kaolinas E 559 lèmé didesnę telyčiu masę 3,58 \% $(\mathrm{p}>0,05)$, telyčių išsaugojimą iki apsiveršiavimo $7,1 \%(\mathrm{p}>0,05)$, vienu ménesiu ankstesnị apsiveršiavimą $(p>0,05)$ ir apsivaisinant $2,4 \%(p>0,05)$ mažiau panaudotų spermos dozių.

2. Bandomosios grupès telyčių kraujyje padidejo hemoglobino $27 \mathrm{~g} / \mathrm{l}(\mathrm{p}>0,05)$ ir gliukozès $0,41 \mathrm{mmol} / \mathrm{l}(\mathrm{p}<0,05)$ kiekis, rodantis intensyvesnę medžiagų apykaitą.

Gauta 20150215

Priimta 20150617

\section{LITERATŪRA}

1. Adamović M., Stojanović M., Grubišić M., Ileš D., Milojković J. 2011. Importance of aluminosili cate minerals in safe food production. Macedonian Journal of Animal Science. Vol. 1. No. 1. P. 175-180.

2. Ambrasūnas L. 2013. Pašarų priedo Kaolinas E 559 itaka kiauliu mésos produkcijai. Kaunas, Kauno medicinos universitetas, 43 p. [žiūrèta 2014-12-18]. Prieiga per internetą: http://vddb. library.lt/fedora/get/LT-eLABa-0001:E.02 2013 ح_20130426_104548-32719/DS.005.0.02.ETD

3. Ani A. O., Ogbu C. C., Iloh E. A. 2014. Response of broiler chicks to diets containing graded levels of clay. Journal of Animal and Plant Sciences. Vol. 24. No. 1. P. 30-34.

4. Demirel R., Yokus B., Senturk D., Ketani M., Baran S. 2011. Effects of dietary zeolite on se- rum contents and feeding performance in rats. International Journal of Agriculture \& Biology. P. 346-350.

5. Grosicki A., Rachubik J. 2005. Influence of bentonite on trace element kinetics in rats. III. Selenium. Bulletin of the Veterinary Institute in Pulawy. Vol. 49. P. 121-123.

6. Huwig A., Freimund S., Kappeli O., Dutler H. 2001. Mycotoxin detoxication of animal feed by different adsorbents. Toxicology Letters. Vol. 122. P. 179-188.

7. Lee S., Kim Y., Kwak W. 2010. Effects of dietary addition of bentonite on manure gas emission, health, production and meat characteristics of Hanwoo (Bos Taurus Coreanae) steers. AsianAustralasian Journal of Animal Sciences. Vol. 23. No. 12. P. 1594-1600.

8. Liang X., Gan Q., Lin J., Qi B., Liu Q., Du Y., Ke F., Zheng S. 2013. Effects of bentonite on rat growth and organ microstructure. Journal of Animal and Veterinary Advances. Vol. 12. No. 6. P. 664-670.

9. Murray H. 2002. Industrial clays case study. Mining, Minerals and Sustainable Development. Vol. 64. P. 1-9.

10. Owen O. J., Nodu M. B., Dike U. A., Ideozu H. M. 2012. The effects of dietary kaolin (clay) as feed additive on the growth performance of broiler chickens. Greener Journal of Agricultural Sciences Vol. 2. No. 6. P. 233-236.

11. Safaei Katouli M., Boldaji F., Dastar B., Hassani S. 2010. Effect of different levels of kaolin, bentonite and zeolite on broilers performance. Journal of Biological Sciences Vol. 10. No. 1. P. 58-62. DOI: 10.3923/jbs.2010.58.62.

12. Safaei Katouli M., Jafariahangari Y., Baharlouei A. 2011. An evaluation on the effects of dietary kaolin and zeolite on broilers blood parameters, T4, TSH and growth hormones. Pakistan Journal of Nutrition. Vol. 10. No. 3. P. 233-237.

13. Trckova M., Matlova L., Dvorska L., Pavlik I. 2004. Kaolin, bentonite and zeolites as feed supplements for animals: health advantages and risks. Veterinary Medicine - Czech. Vol. 49. No. 10. P. 389-399.

14. Utizhev A. 2011. Nauchnoe obosnovanie i effektivnost' ispol'zovaniya bentonitosoderzhashchey dobavki $v$ zhivotnovodstve: avtoreferat disertacii doktara sel'skokhzaystvennykh nauk. S. 366.

15. Wafar R. J., Gabdo I. I., Bilham D. Y., Onaleye K. J., Ojinnaka E., Bilham R. Y. 2014. Effects of kaolin supplementation on growth performance, carcass characteristics and hematological indices of weaner rabbits. International Journal of Applied Sciences and Engineering Research. Vol. 3. No. 1. P. 91-98. 
Arvydas Kardišauskas, Rima Kregždytė

\section{INVESTIGATION OF IMPACT OF KAOLIN E 559 ON CALF GROWTH, DEVELOPMENT AND RE- PRODUCTION}

\section{Sum $m$ ary}

Economic efficiency of heifer breeders' farming activity depends not only on animal optimal growth and development indicators but also on their reproductive properties. Importance of reducing the cost of milk production urges them to look for ways to grow heifers economically. One of the measures is the use of aluminosilicate food supplements.

The aim of the paper is investigating the effects of kaolin E 559 on heifer growth, development and reproduction.
The study was conducted to determine the effects of kaolin E 559 on heifer growth and reproduction. Two groups of Lithuanian Black and White calves (control and experimental) have been formed with 15 in each group. The test was carried out on the day of birth of the calf 5-12 months of age. Heifers were grown in one barn and on equal conditions, only the test group were given additional kaolin $(100+2.5 \mathrm{~kg}$ of concentrated feed kaolin). The test group had a daily weight gain of $3.58 \%$ higher than the control ( $p>0.05)$, the total gain higher by $3.96 \%(\mathrm{p}>0.05)$, more haemoglobin $27 \mathrm{~g} / \mathrm{l}$ $(\mathrm{p}>0.05)$, and glucose $0.41 \mathrm{mmol} / \mathrm{l}(\mathrm{p}<0.05)$ in the blood test. Heifers of the test group had better insemination success rate by $2.4 \%(\mathrm{p}>0.05)$, and calved one month earlier than heifers in the control group $(\mathrm{p}>0.05)$.

Key words: kaolin E 559, heifers, calf growth, reproduction 